Review

\title{
Framing Smart Meter Feedback in Relation to Practice Theory
}

\author{
Hanna Mela ${ }^{1, *}$, Juha Peltomaa ${ }^{1}{ }^{\mathbb{D}}$, Marja Salo ${ }^{1,2}{ }^{\mathbb{D}}$, Kirsi Mäkinen ${ }^{1}$ and Mikael Hildén ${ }^{1}$ \\ 1 Finnish Environment Institute, P.O. Box 140, FI-00251 Helsinki, Finland; juha.peltomaa@ymparisto.fi (J.P.); \\ marja.salo@ymparisto.fi (M.S.); kirsi.makinen@ymparisto.fi (K.M.); mikael.hilden@ymparisto.fi (M.H.) \\ 2 Faculty of Biological and Environmental Sciences, University of Helsinki, P.O. Box 65, \\ FI-00014 Helsinki, Finland \\ * Correspondence: hanna.mela@ymparisto.fi
}

Received: 29 August 2018; Accepted: 28 September 2018; Published: 3 October 2018

\begin{abstract}
Smart metering is advancing rapidly and consumption feedback from smart meters is expected to help residents to reduce their energy and water consumption. In recent years, more critical views have been expressed based on theories of social practice, arguing that smart meter feedback ignores the role of various mundane practices where energy and water are consumed and instead targets individuals as active decision-makers. We present a review of qualitative studies on smart meter feedback and results of a survey to European smart metering projects. We argue that theories of social practice can be used to reframe the challenges and potentials of smart meter feedback that have been identified in the literature and our survey. This presents challenges of smart meter feedback as resulting from normalised resource intensive practices rather than from uninterested and comfort-loving individuals. Potentials of improving the effectiveness of smart meter feedback relate to supporting communities and peer-learning and combining smart meter feedback with micro-generation of renewable energy. This has implications for how domestic energy and water consumption is targeted by policy.
\end{abstract}

Keywords: smart metering; feedback; households; energy and water consumption; theories of social practice

\section{Introduction}

Energy consumption is a key contributor to climate change, and a continuously increasing level of energy consumption is unsustainable with the current energy mix that is heavily based on fossil fuels [1]. Water consumption in many parts of the world has already exceeded sustainability limits, leading to declining groundwater levels and river flows in densely populated areas [2]. While water scarcity itself is a problem, household water usage is also closely linked to energy consumption due to water heating.

Demand management is increasingly seen as a way to decrease both overall consumption of resources such as energy and water and to deal with peak loads that are particularly problematic for system management. Demand management can involve different types of energy users but in this paper, we focus exclusively on households. Smart metering has been identified as an important element of demand side management and the development of smart grids [3,4] that would lead to a transition towards low carbon energy systems.

Smart metering can be linked to the concept of energy transition. There is no standard definition of energy transition, but it usually refers to a change in an energy system, involving for example, changes of fuel sources, technologies and a whole set of actors including suppliers, distributors and end users $[5,6]$ or structural changes in the way energy services are delivered [6]. In this paper we use the 
term energy transition to refer to a systemic change from (the current), fossil-fuel based energy system where residents are mere consumers of energy, towards a system based on intermittent renewable energy sources and also involving power generation in smaller units, including the household and community level. The role of residents is expected to change in future smart energy systems and concepts of 'energy citizen' or 'citizen-consumer' and 'co-provider' have been used to describe residents who are actively engaged in the management of energy $[7,8]$. There are already examples of communities of front-runners in which learning from peers has contributed to increasing energy efficiency [9-11]. In a more critical context, the concept of 'Resource Man' has been introduced [12], referring to the ideal energy consumer that smart metering projects are targeted to.

The objectives of smart electricity metering range from peak load management and reducing total demand to fraud detection and accurate billing [13] (p. 447). In the case of water metering, improved leak detection is also an important factor motivating smart meter roll-outs, in addition to the aim of decreasing the overall consumption of water e.g., [14]. There is variation in what residents see of the meters, from no direct information to in-home displays, websites or mobile applications visualising consumption in real-time [15].

Large smart metering roll-out programs are under way or being planned throughout the developed countries. It is expected that by 2020 nearly $72 \%$ of European consumers will have a smart meter for electricity and $40 \%$ for gas [16]. The Energy Efficiency Directive of the EU also encourages the use of in-home displays [17], and the EU's 2015 Strategic Energy Technology Plan emphasises the need to provide smart solutions for energy consumers to enable them to optimise their energy consumption (and production) [18].

Despite the expectations for smart metering, empirical analyses of the effects of smart meter feedback show mixed results. Some review studies have indicated energy or water savings within the range of 5 to $15 \%$, at best nearly $30 \%$ [14,19-21]. A meta-analysis looking at the effect of different information and feedback strategies on energy consumption found an average reduction of $7.4 \%$, with the most effective interventions including relatively high involvement such as home audits and individual energy consultation [22]. Some studies report modest $(2-4 \%)$ reductions [23] or no statistically significant reductions [24,25]. Studies looking at the effect of smart meter feedback have been criticised for not being always able to differentiate between the effects of feedback, self-selection bias of the participants and/or the Hawthorne effect (participants behaving differently because they know they are taking part in a study). The long-term sustainability of achieved savings has also been questioned [26-28]. As a result, a growing body of literature questioning the optimism related to smart meter feedback has emerged [29]. This gap between expectations and actual experiences calls for investigations of the underlying reasons for energy and water consumption. Practice theories can help to formulate and address relevant research questions, as they place smart meters in the context of everyday practices [12].

Both energy and water consumption are embedded in everyday practices such as cooking, laundering, cleaning or showering [30]. Energy and water consumption are not practices in themselves but rather a by-product, 'just what happens while going about our daily lives' [31]. Following this line of thinking, a focus on practices helps to extend the scope from flows of resources to the meaningful activities they enable. In this paper we explore the challenges and potentials related to the interaction between residents and smart meters through the lens of social practice theories. This leads to a discussion on what smart metering can and cannot do in contributing to energy transitions. The questions guiding our analysis are:

- What challenges and potentials related to smart meter feedback have been identified?

- How can the identified challenges and potentials be analysed and reframed through theories of social practice?

- Can smart meter feedback support energy transitions? 
Our conceptual approach is based on practice theories, e.g., Reference [32], implying that patterns of energy and water consumption change when links between the elements of energy and water consuming practices are broken or created. We review key literature on smart metering trials where attention has been paid to the interaction between residents and smart meters, in order to explore the challenges and potentials related to smart meter feedback.

The paper is organised as follows. In Section 2 we first introduce our conceptual approach to smart metering, after which our data and methods are described in Section 3. In Section 4 we present results from the reviewed literature and a survey we have conducted, identifying challenges and potentials for effective smart metering and interpreting these based on practice theories. Section 5 reflects on the results in the light of practice theories and discusses whether smart metering could contribute to energy transitions. Section 6 summarises key findings and gives recommendations for the development of smart meter feedback.

\section{Conceptual Approach}

Smart meter feedback is assumed to make rational consumers alter their behaviour in response to information about their consumption (and the related costs). This assumption has in recent years been challenged by some researchers, and more critical approaches to smart metering have been expressed. Yolande Strengers [12] (p. 2) argues that the global vision for smart energy technologies is part of a 'Smart Utopia' that is underpinned by a smart ontology, in which human action and social change are understood as being mediated by information and communication technology (ICT) and data. In a Smart Utopia, environmental problems are solved with the help of new technology without compromising current lifestyle. In this vision, technologies, such as smart meters, act in various roles: They promise rational and efficient control of residents, they assign responsibility for complex environmental problems to individuals rather than states or companies and they 'seamlessly manage the home environment while maintaining or enhancing current lifestyle expectations' [12] (p. 8, 23). This vision is based on viewing residents as highly informed and rational micro-resource managers of energy (and water), who are interested in their own consumption and manage it with the help of smart meter feedback. The concept of 'Resource Man' has been introduced to describe this type of an ideal energy consumer that smart metering projects are targeted at. 'Resource Man' is described as a 'gendered, technologically minded, information-oriented and economically rational consumer of the Smart Utopia' [12] (pp. 36, 54).

In contrast to the smart ontology, Strengers [12] uses the ontology of everyday practice, in which 'human action and social change is mediated by and through participation in routinely performed practices'. Energy and water are not valuable in themselves, but they are merely 'ingredients' [30] or 'resources' [33] that enable domestic practices, but operate in the background without the resident paying attention to them. When smart meter feedback concentrates solely on energy or water as commodities, measured in $\mathrm{kWh}$ or litres, it ignores the role of practices in which they are consumed [12].

These ideas belong to an increasing body of literature on theories of social practice. Practice theories build on the works of e.g., Giddens [34] and have been developed further by e.g., Schatzki [35], Reckwitz [36] and Shove et al. [32]. As interpretations of the practice approach vary between scholars, the theory is often referred to in plural [32], as we also do in our paper. In practice theories, the unit of analysis and enquiry is social practice, which has been defined as a 'routinised type of behaviour' [36] (p. 249), which 'endures between and across specific moments of enactment' [37]. Practices consist of three elements: Materials, competences and meanings. Materials include all tangible objects, infrastructure and technologies, competences include skills, know-how and technique, and meanings encompass ideas, aspirations and symbolic meanings [32]. A practice exists simultaneously as a performance and as an entity [36] (p. 249), [32]. Practice as a performance is the observable behaviour of individuals, such as heating or cooling spaces, cooking or showering. However, when practices are understood as entities, it becomes clear that the observable behaviour (practice as performance) is not a 
result of individual choices but by nature social, embedded in socially shared ideas and meanings. Seen in this way, the observable behaviour of individuals is only the 'tip of the iceberg' [38], underpinned by socially shared elements of practice: Competences, materials and meanings. Examples of this analytical distinction are described in Table 1.

Table 1. Elements of practice as an entity. Adapted from [38].

\begin{tabular}{llc}
\hline \multicolumn{2}{c}{$\begin{array}{c}\text { Observable Behaviour of Individuals (Practice as Performance): } \\
\text { e.g., Heating or Cooling Spaces, Cooking, Showering, Watching TV etc. }\end{array}$} \\
\hline \multicolumn{1}{c}{ Skills and Competences } & Materials and Infrastructure & $\begin{array}{c}\text { Socially Shared Meanings } \\
\text { and Conventions }\end{array}$ \\
\hline $\begin{array}{l}\text { (Embodied) knowledge and } \\
\text { skills needed to perform } \\
\text { practices, knowing how to use } \\
\begin{array}{l}\text { appliances, timing and ordering } \\
\text { of activities etc. }\end{array}\end{array}$ & $\begin{array}{l}\text { Constant availability of heat, } \\
\text { electricity and hot water, showers } \\
\text { installed in bathrooms, ovens in } \\
\text { kitchens, availability of a TV }\end{array}$ & $\begin{array}{l}\text { Ideas of 'normality', ideas of } \\
\text { comfort, socially accepted ways of } \\
\text { e.g., eating and levels of } \\
\text { cleanliness }\end{array}$ \\
\hline
\end{tabular}

Each practice-as-entity has its history and a trajectory along which it develops. A process of co-evolution happens between technologies and infrastructures, competences and meanings that together constitute a practice. The development paths of practices illustrate how normality is constructed and how unsustainability can become standardised. When certain expectations of comfort, cleanliness and convenience have become standardised, in terms of what is regarded as 'normal', patterns of consumption may escalate as what previously was regarded as 'luxury' gradually becomes 'normal'. These developments have led to more energy-intensive lifestyles [39]. For example, air-conditioning has become normalised in many countries, making passive thermal design in buildings more rare [39]. An example related to water consumption is how the frequency of washing bodies and clothes has increased, rendering daily showering and frequent laundering normal practices and thus increasing water consumption [40,41].

Practices are, on the one hand, relatively stable and to an extent resist change, which emphasises their path-dependent character. On the other hand, people, when performing practices, also create possibilities for change by experimenting, adapting and improvising. Even though there is individual variation between performing a practice, practices are social by character and individuals participating in them seek recognition as competent practitioners by performing practices well, according to the shared standards and understandings of normality, which vary between social groups and geographical contexts [42]. The importance of communities for developing low-carbon ways of living and challenging conventions has been recognised in previous research. Communities hold potential that individuals alone do not have [43].

Practice theoretical approaches differ from research focusing on individuals as active decision-makers, which is often presumed in consumption feedback studies. Approaches focusing on individuals see behaviour as a set of choices determined by identifiable factors, including attitudes and values and have been described as the 'ABC paradigm', A standing for attitude, B for behaviour and $C$ for choice [44]. This paradigm draws on economic theories and psychology, for example on the theory of planned behaviour [45]. In the language of the ABC, there are barriers and motivators for individuals to change their behaviour, and the role of policy is to remove those barriers and persuade individuals to make sustainable choices [32]. The distinction between the two approaches is illustrated in Figure 1a,b. In Figure 1a, residents are presented as rational managers of resources. In Figure 1b, residents are practitioners taking part in social practices, each of which consists of the interlinked elements of competences, materials and meanings. Practices are sequenced and linked with each other in time and space. They may also overlap in timing, location and elements. Consumption of resources such as energy and water is an integrated part of practices but is essentially instrumental rather than an end in itself. 


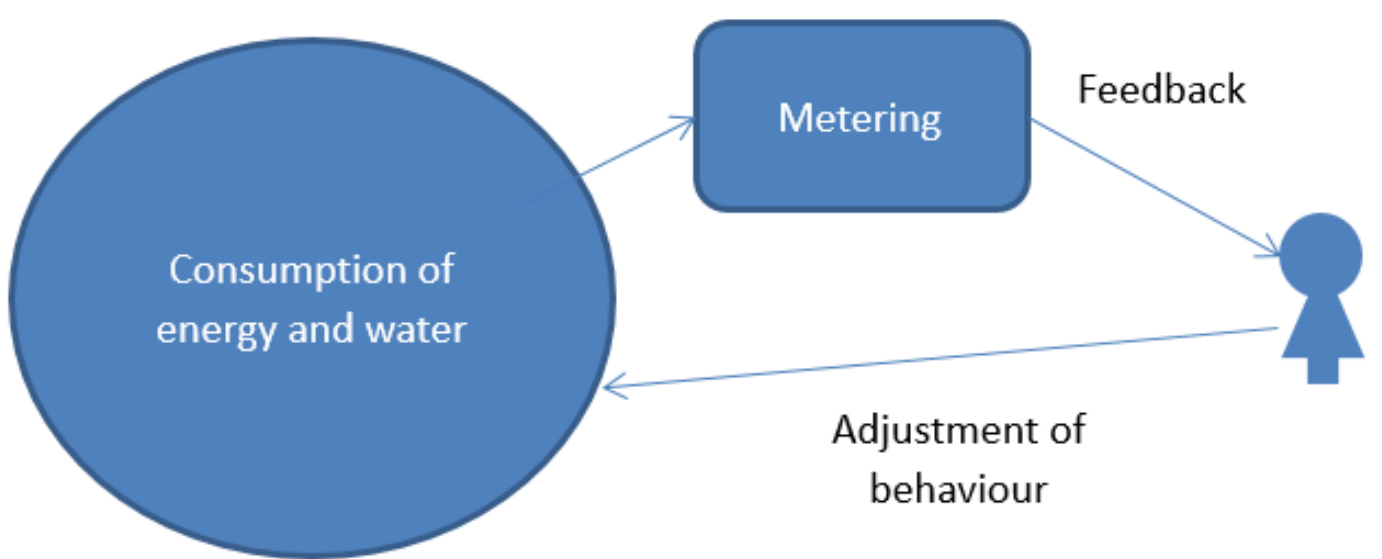

(a)

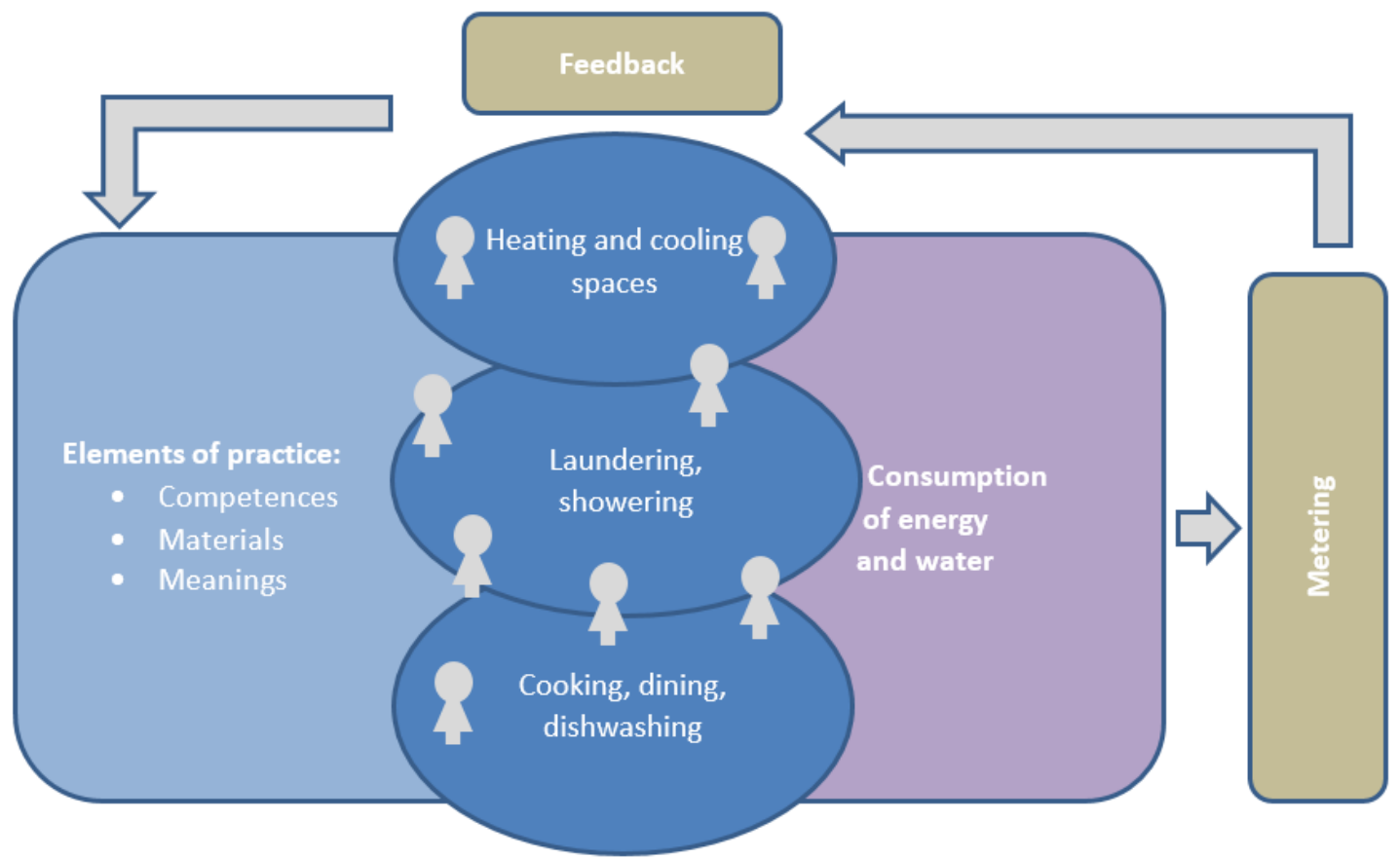

(b)

Figure 1. (a). Smart meter feedback according to the ABC paradigm; (b). Smart meter feedback in the context of everyday social practices.

Despite the criticism of smart metering and rational optimisation of energy consumption, there have also been attempts to see if and how smart metering could become a more integrated element of different practices contributing to energy transition. It has been suggested that smart systems, including smart metering, could be an element in potentially emerging home energy management (HEM) practices involving energy monitoring, microgeneration, energy storage, energy trading/sharing, timing of demand and energy conservation, which are being promoted by smart grid development [46].

HEM-practices could support energy transitions, and three orders of sociotechnical innovation related to energy transitions have been suggested. The orders differ in terms of the level of integration between domestic consumption practices and HEM-practices [46]. The first order innovations do not change the basic set-up of the household and its connection with the wider energy system, and do not connect domestic consumption practices with HEM-practices. Examples include using 
an in-home energy display to monitor consumption or substitution of old appliances with more energy efficient ones. In second order innovations there is a stronger connection between HEM and domestic consumption practices, as well as the wider energy systems, e.g., timing of laundry or vacuuming practices to fit local energy production in order to de-link consumption from carbon intensive production and distribution practices [46]. Third order innovations present a more radical departure from the current system, involving increasingly sharing the tasks and responsibilities for energy production and distribution practices between households, existing service providers and new intermediaries (ibid.). Third order innovations can also involve energy self-sufficient districts or energy cooperatives, transferring the power from centralised to de-centralised actors. In one scenario households belong to a personal carbon allowance trading scheme, and some domestic consumption practices are no longer private but become shared, e.g., through shared cars and shared laundry and cooking facilities [46] (pp. 130-133). For our study, the three orders of innovations provide a benchmark to look at the level of integration of smart meter feedback into practices.

\section{Data and Methods}

We carried out a literature review and conducted a survey within a sample of European smart metering projects in order to analyse what issues are seen as limiting the effectiveness of smart meter feedback and what issues, on the other hand, are seen as potentials for effective smart meter feedback, within a sample of European smart metering projects. The type of the review is integrative. An integrative literature review has been defined as 'a form of research that reviews, critiques and synthesises representative literature on a topic in an integrated way such that new frameworks and perspectives on the topic are generated' [47]. Articles for the literature review were searched in the Web of Science in January 2017, where we restricted the analysis to papers published in the last 10 years (between 2007 and 2017). The search was repeated in September 2018 to cover articles published in 2017 and 2018. Several combinations of keywords were tested, and a search was done with the following set of keywords: TS $=\left(\right.$ Domestic OR household $*$ OR residen* OR consumer $\left.{ }^{*}\right)$ AND TS $=\left(\right.$ electric $^{*}$ OR energ* OR heat ${ }^{*}$ OR water) AND TS $=($ meter* OR feedback OR smart) AND TS $=($ behav* OR awareness) $\mathrm{AND}$ TS $=\left(\right.$ conserva ${ }^{*} \mathrm{OR}$ sav $^{*} \mathrm{OR}$ reduc $\left.{ }^{*}\right)$.

We focused on studies where the main aim has been to affect overall consumption and in some cases also load shifting by providing consumption feedback information in the form of a smart meter display or similar medium. Our focus is on the challenges and potential of smart meter feedback to affect overall energy and water consumption. Thus, we have excluded papers from our review where the focus has been only on load shifting. Most of the available research addresses smart electricity metering, while smart water, heat or gas metering have been studied less. Therefore, most of the articles we have reviewed concentrate on smart electricity metering. However, several domestic practices use both energy and water simultaneously (e.g., laundering, dishwashing, showering). The background assumption of smart meter feedback (i.e., provision of consumption data to residents makes them reduce their consumption) is the same, regardless of whether the resource is electricity, water, gas or heat.

In order to better understand the potentials and challenges of smart metering feedback in relation to practices, we have limited our analysis to studies that have qualitatively addressed the interaction between residents and smart meter feedback. Thus, studies that have concentrated on quantitatively measuring the achieved savings, customer satisfaction of smart meter trials or comparing different features of in-home displays and the residents' preferences regarding the display features but not addressing the residents' experiences in more detail have been excluded, along with studies looking at smart metering from the point of view of utility companies, for example its economic profitability. Another requirement was that the trials should enable residents to monitor their consumption and access their consumption data via an in-home display, mobile application or a website. The final sample included 20 articles, which are listed and briefly described in Appendix A. These articles form our core material. In addition, we use a larger body of literature on smart metering and energy and water 
feedback to support our analysis. The reported trial settings vary according to their size, duration, whether the participants volunteered or not, or whether other interventions e.g., energy efficiency measures were introduced at the same time. In some studies, changes in consumption were measured or a quantitative survey accompanied the qualitative analysis, but our focus is on the qualitative data, most of which consists of interviews. Only articles containing new empirical material were included in our sample, thus excluding review articles. The analysis is qualitative. We have read through the final sample of articles, collected and grouped all the identified challenges and potentials and organised them under the three elements of practice theories (materials, competences and meanings).

In addition to the literature review, we use data from an online survey. The survey questions were formulated based on an analysis of documents describing metering initiatives in various European countries. Information about these metering projects was collected on the ICLEI (International Council for Local Environmental Initiatives) website in the form of documents and descriptions on metering projects' websites, as well as with a snowball method from these websites and documents and through the researchers' contacts. The survey was sent in December 2016 to 39 organisations that have implemented energy and/or water metering trials in Europe. Of these, 11 responded. The responses covered 15 smart metering projects in 10 European countries. The aim of the survey was to gather information on the barriers and enablers of European metering projects and the role of residents in them. The survey contained multiple choice and open-ended questions related to these themes. The results of the survey are used to complement the results of the literature review.

From the literature we have identified challenges and on the other hand, potentials of smart metering in the spheres of competences and skills, materials and infrastructures, and socially shared meanings. We have applied practice theories to reframe these three spheres to assess the possibilities to tackle the challenges and harness the potentials.

\section{Results}

In this section we present our findings on the challenges and potentials identified in the analysed articles and the survey. We summarise our findings as described in the literature and in parallel interpret them in the light of the theories of practice presented in Section 2.

Through the interpretation we shift perspective from the meters, management and data to challenges and potentials in the light of the everyday practices that people already carry out in order to complete meaningful tasks. We link the observations from the survey with those reported in the reviewed literature to identify supporting or conflicting findings.

\subsection{Challenges Related to Smart Meter Feedback}

In Tables 2-4, we summarise the challenges of smart metering as identified in the literature and interpret the observations from a practice theories perspective. The challenges are grouped into the three categories of practice elements: Competences and skills, materials and infrastructures and socially shared meanings.

\subsubsection{Challenges Related to Competences and Skills}

First, we look at what in the practice terminology is referred to as competences and skills (Table 2). In the literature, insufficient knowledge and inactivity of residents is often referred to as hindering energy or water saving. 
Table 2. Challenges of smart meter feedback related to competences and skills as identified in the literature and as interpreted through theories of social practice.

\begin{tabular}{|c|c|}
\hline \multicolumn{2}{|c|}{ Challenges of Smart Metering Feedback Related to Competences and Skills } \\
\hline Identified in the literature & Interpreted through theories of practice \\
\hline $\begin{array}{l}\text { Residents' knowledge on energy or water } \\
\text { consumption is insufficient. Smart meter feedback is } \\
\text { perceived as too complicated and abstract by } \\
\text { residents in general [27,48-53], and by the elderly } \\
\text { population in particular [48]. Residents are not } \\
\text { interested in monitoring their } \\
\text { consumption }[27,48-51] \text {. }\end{array}$ & $\begin{array}{l}\text { Competence and skills that save energy or water are } \\
\text { currently not integral to the practices where energy and } \\
\text { water are used. Understanding energy or water use at } \\
\text { an abstract level is not relevant for the performance of } \\
\text { domestic practices. }\end{array}$ \\
\hline $\begin{array}{l}\text { After an initial interest in the new 'gadget' and } \\
\text { playing with it, smart meters tend to get } \\
\text { 'backgrounded' and forgotten }[31,51,54-57] \text {. }\end{array}$ & $\begin{array}{l}\text { Smart meters do not manage to successfully connect to } \\
\text { existing practices where energy and water are used and } \\
\text { remain isolated from them. They do not support or } \\
\text { strengthen competences that would use less energy or } \\
\text { water. Thus, they are rarely able to change the practices. }\end{array}$ \\
\hline $\begin{array}{l}\text { Residents do not know how to further save energy or } \\
\text { water. Smart meters do not provide any assistance } \\
\text { with how to actually organise daily activities in a way } \\
\text { that would save energy and water. }[47,50,51]\end{array}$ & $\begin{array}{l}\text { From a practice perspective, the observation on the lack } \\
\text { of assistance to organise daily activities is valuable. } \\
\text { Competences related to energy or water saving cannot } \\
\text { be built simply by providing consumption feedback. }\end{array}$ \\
\hline
\end{tabular}

Lack of knowledge and interest among residents was also seen as a challenge to the effectiveness of smart meter feedback by nearly all the respondents of our survey, and residents were characterised as apathetic and uninterested. Within this kind of problem-framing (residents are not interested, they quickly lose interest) attempts to improve the effectiveness of the intervention are typically reduced to making the feedback more salient and diverse by adding more features to it in order to prevent the residents from losing their interest, e.g., [56]. This is in line with Figure 1a, a simple feedback loop where information directly affects the way resources are used. From a point of view of practice theories, the impact of information provision efforts on the way energy and water are used can be questioned. The challenge identified in the literature is that residents do not (know how to) use the meter and data in their daily lives. Practice framing would turn the problem around: People already have knowledge and skills to go on with their everyday activities but lack knowledge and skills to embed and translate feedback from the meters to transform the way they perform practices. The elderly has been recognised as a group that faces special challenges in engaging with smart meter feedback [48].

\subsubsection{Challenges Related to Materials and Infrastructures}

Access to unlimited volume of energy and (hot) water, and appliances to assist in housekeeping and cleanliness form an important material element of daily energy and water consuming practices. The material elements have evolved over time, at the same time shaping domestic practices and changing our perceptions about standards of cleanliness and comfort. Smart meter feedback always takes place in a material context, which may sustain energy and water intensive practices and thus pose a challenge for the effectiveness of smart meter feedback (Table 3). 
Table 3. Challenges of smart meter feedback related to materials and infrastructures as identified in the literature and as interpreted through theories of social practice.

\begin{tabular}{cc}
\hline \multicolumn{2}{c}{ Challenges of Smart Meter Feedback Related to Materials and Infrastructures } \\
\hline \multicolumn{1}{c}{ Identified in the literature } & Interpreted through theories of practice \\
\hline $\begin{array}{c}\text { Technical problems related to the installation and } \\
\text { functioning of smart meters, e.g., reception issues or } \\
\text { sensor faults [27,52,56,58,59]. }\end{array}$ & $\begin{array}{c}\text { These observations do not relate to any material } \\
\text { elements of existing practices but rather highlight } \\
\text { the material essence of the meter itself. Technical } \\
\text { problems are associated with reliability and can } \\
\text { form an obstacle for smart meters to become a } \\
\text { material element of practices as intended. }\end{array}$ \\
$\begin{array}{c}\text { Housing developers, local authorities and manufacturers of } \\
\text { appliances create hindrances to making use of smart meter } \\
\text { feedback and thus energy saving, for example by making the } \\
\text { installation of heat pumps or micro-generation of renewable } \\
\text { energy difficult or not being proactive about energy efficiency } \\
\text { in the design of new buildings and appliances [55,60]. }\end{array}$ & $\begin{array}{c}\text { The material elements underlying current energy } \\
\text { and water consuming practices are often complex } \\
\text { and expensive and therefore slowly replaced. }\end{array}$ \\
$\begin{array}{c}\text { Although energy efficiency has become a selling } \\
\text { point, the material elements do not address the } \\
\text { rebound effect related to increased use. }\end{array}$ \\
\hline
\end{tabular}

The results of our survey are to a large extent in line with the results of the literature review regarding material elements. However, various technical problems were represented in our survey as the most important factor limiting the effectiveness of smart metering, while in the reviewed literature technical issues were rather rarely mentioned. This underlines that a functioning technology is crucial for smart metering [61], which in itself is not surprising, but may obscure the important interactions between technologies and practice. Although a functioning technology is a prerequisite for the smart system to be integrated into practices, technically viable solutions do not guarantee that the technology will become part of relevant practices. The metering projects aimed at providing material elements for consumers with an objective to encourage them to come up with practices to manage resource consumption. However, what seems to be missing is a link between the new material component and other elements of existing practices. Our findings from the review and the survey support the notion that the elements of practices and links between them need to change in a consistent way in order to increase the likelihood of achieving the final goal: more sustainable patterns of resources use (Figure 1b).

Other, nearly as important limiting factors recognised in the survey were the residents' low interest in their energy and water consumption and habits and culture regarding energy and water consumption. From a practice perspective, it is interesting that one respondent highlighted how customers were only interested in data when it was related to specific events. A practice interpretation of the low interest emphasises the instrumental and invisible role of the flows of energy and water in conducting meaningful practices.

A third finding from our survey regarding the materiality of the smart meter is that in the trials that responded to it, the most common means to access the information was via a website. This is rather disconnected from the actual practices that consume water and energy. Based on the objectives of the projects and the focus on metering, many projects aimed at introducing new practices of managing energy, but these did not often realise as intended. The survey responses indicate that parallel measures to support users and provide financial incentives would be needed to support the residents' engagement with consumption data more actively. Our interpretation is that if the objective is to introduce new practices of managing energy in households, the practice approach would be useful in mapping the elements of practice that need to be reconfigured instead of simply focusing on introducing a specific technology (Figure 1b).

\subsubsection{Challenges Related to Socially Shared Meanings}

The third category of challenges is related to socially shared meanings (Table 4). The literature highlights numerous observations related to the taken-for-granted levels of comfort that are difficult to challenge. 
Table 4. Challenges of smart meter feedback related to socially shared meanings as identified in the literature and as interpreted through theories of social practice.

\begin{tabular}{l} 
Challenges of Smart Meter Feedback \\
\hline Identified in the Literature \\
\hline Residents are not willing to compromise certain \\
living standards and to reduce their consumption. \\
Certain appliances and perceived levels of comfort \\
are not negotiable and residents receiving smart \\
meter feedback become defensive about \\
them $[27,51,55,56,58,60,62,63]$.
\end{tabular}

Smart meter feedback only appeals to a small group of 'monitor enthusiasts' who are already interested in following their energy consumption, leaving the large audience unaffected $[27,56,58]$.

Unequal participation of household members. Smart metering projects have often appealed to the technically minded, typically male members of households, leaving other family members more passive [27,31,52-55,57,60,63-65].

Smart meter feedback can serve as a 'normaliser' of consumption, as residents receiving smart meter feedback quickly develop a sense of their usual level of consumption. Smart meter feedback helps to identify abnormal, excess use and 'waste', at the same time legitimising certain basic level of consumption $[27,52,57,59,60,64]$.

Residents see themselves as energy or water efficient and do not see how they could further save energy or water $[27,31,50,52-54,58,59]$.

Residents refer to the importance of health and well-being, especially of children or the elderly, and maintaining harmony in the home. The goal of energy saving is perceived as conflicting with these aims $[27,58,60,63]$.

Residents have feelings of distrust towards utilities and smart meters and are concerned about loss of privacy or autonomy. Smart meters blur the boundaries between the private and the external and are sometimes hidden from sight by residents who feel they are too visible in the home environment. Smart meters cause conflicts between family members $[27,49,53,56,65]$.

There is not enough economic incentive for residents to engage with smart meter feedback as the average achieved economic savings are too small to motivate changes in daily routines $[27,52,55,58,60]$.
Meanings of comfort and normality are integral to many practices where energy and water are consumed. Rather than focusing on individuals and their feelings, practice theories try to understand the trajectory of socially shared meanings related to those mundane domestic practices where energy and water are consumed. By examining how these meanings have developed over time, how they are currently sustained and how they are changing, insights can be gained that help to identify paths to more sustainable practices.

These 'monitor enthusiasts' can be seen as the early adopters of a practice of energy monitoring. Whether this practice manages to recruit larger groups of practitioners depends on the broader context where domestic energy and water consuming practices take place.

Patterns of inequality and power are present in practices, as well as shared conventions, roles and responsibilities related to e.g., gender and age within households. These are reflected in the way smart meter feedback is received and used in households.

Meanings of normality are important in understanding how certain practices become established as part of everyday life. Smart meter feedback is not capable of challenging meanings of normality. Rather, it may serve to confirm what is already regarded as normal.

Purposeful 'wasting' of energy and water is not part of practices, but the 'normality' of practices hides resource intensive ways of living that residents do not easily question.

Saving energy is not currently involved as an element in domestic practices, while other meanings such as care and well-being especially of children and the elderly, belong to the energy-intensive practices of heating and cooling.

Meanings of privacy and autonomy that are integral to domestic practices are threatened when smart meters presume disclosure of consumption information vertically (between household and utility) or horizontally (between or within households, e.g., between parents and children).

These observations reflect a view of residents as rational individuals who respond to economic incentives by weighing the costs and making decisions based on the smart meter feedback. This assumption is questioned by practice theories. However, a wider economic context is important for how energy and water consuming practices have developed over time and how they will develop in the future. 
As seen in the results Tables 2-4, the analysed literature has its main focus on individuals, their attitudes and feelings, preferences and behaviour. These challenges look different when the focus is on the social practices where energy and water are consumed rather than on the individuals that consume. As highlighted in Section 4.1.2. on challenges related to material elements, availability of resources and appliances have normalised increasing standards of comfort and cleanliness and as a result also practices have changed. Pure consumption-based feedback may not be powerful enough to affect practices if material elements and socially shared meanings remain unchanged (Figure 1b).

When discussing the absence of a supportive policy and market context, theories of social practice would pay attention to the ways policies have shaped and sustained the unsustainable ways of life with high energy and water consumption. The residents' experience that it is not easy to save money when trying to save electricity [60] may be well justified. However, the conclusion according to practice theories would not straightforwardly claim that residents need more economic incentives to make better choices. Pricing of energy and water does play a role in creating meanings of abundancy or scarcity, but above a certain minimum level of income the pricing may be less important than the ideas of normal levels of comfort, cleanliness and convenience, which have co-evolved with infrastructure, policy and technical development of appliances.

The importance of a practice-based perspective is illustrated by the reported observation that residents find the shifting of activities to low-peak periods of the day inconvenient $[31,52,63]$. This does not clearly relate to only one element of practices, but rather emphasises the role of the organisation and sequences of daily activities and the connections between practices. The temporal flexibility of practices varies considerably, dining being among the least flexible domestic practices as it is tied to bodily rhythms as well as timing of work, study and leisure activities [66].

\subsection{Potentials of Smart Meter Feedback}

In Tables 5-7, we summarise the potentials of smart metering and suggested ways of improving it. Similarly as the challenges in the previous section, the potentials are grouped into the three categories of competences and skills, materials and infrastructures and socially shared meanings.

\subsubsection{Potentials Related to Competences and Skills}

Potentials related to competences and skills (Table 5) show that the role of improving the provision of information is central in the literature.

Table 5. Potentials of smart meter feedback related to competences and skills as identified in the literature and as interpreted through theories of social practice.

\begin{tabular}{|c|c|}
\hline \multicolumn{2}{|c|}{ Potentials of Smart Meter Feedback Related to Competences and Skills } \\
\hline Identified in the literature & Interpreted through theories of social practice \\
\hline $\begin{array}{l}\text { Smart meter feedback functions as a learning tool, } \\
\text { increasing the residents' awareness and } \\
\text { understanding of their energy and water } \\
\text { consumption }[27,31,50-55,57,59,60,63-65]\end{array}$ & $\begin{array}{l}\text { Smart meter feedback evidently increases knowledge } \\
\text { of energy and water consumption among (some) } \\
\text { residents. However, this increased knowledge does } \\
\text { not automatically actualise as reduced consumption, } \\
\text { because consumption results from practices that do } \\
\text { not change simply by providing information. }\end{array}$ \\
\hline $\begin{array}{l}\text { Tailoring smart meter feedback to various user } \\
\text { groups and contexts, in order to make consumption } \\
\text { data more relevant and interesting }[50,56,64,67] \text {. }\end{array}$ & $\begin{array}{l}\text { Paying attention to the variation among individuals } \\
\text { and social contexts where domestic practices are } \\
\text { performed makes feedback less general and can } \\
\text { create a stronger link to specific practices. }\end{array}$ \\
\hline $\begin{array}{c}\text { Using smart meter feedback as an educational aid } \\
\text { in school projects among children and young } \\
\text { people }[52,60,67]\end{array}$ & $\begin{array}{l}\text { In these examples smart meter feedback is adopted as } \\
\text { an element in teaching practices. }\end{array}$ \\
\hline
\end{tabular}


In our survey, the importance of choosing simple enough smart metering technology that suits the residents' needs was emphasised as the most important success factor for smart metering projects. This may reflect the fact that the meter and monitoring activities as such are not important but how these can be embedded in other meaningful practices. In addition, the importance of recognising windows of opportunity to disrupt current patterns of consumption (see also Reference [11]) was mentioned in the survey.

Providing comparative consumption data within a peer group was considered important by most respondents of our survey, while most of the reviewed studies did not address comparative feedback. Some researchers have paid attention to the potential 'boomerang effects' of social comparisons, if residents who are defined as 'low users' increase their consumption [28] as the "normal" level justifies higher consumption. Others [67] note that contextualising feedback by providing social comparisons with the community was experienced positively by most residents participating in the trial but a negative sense of competition was felt by some. There is some indication that co-designing smart meter feedback together with residents can yield higher engagement with the feedback [68]. Smart meter-based gamification of energy and water consumption has also successfully managed to engage residents and resulted in reductions of water consumption in a small trial setting [69]. From a practice theories approach this could be seen as recruiting individuals to a practice of playing a game, which, when played by its rules, results in reduced water consumption. Practice theories would also invite us to focus on how smart meter feedback is embedded in the current arrangement of elements of practice, not only on interactions of metering feedback and the user.

From a practice perspective tailoring feedback makes sense in that the contexts in which practices take place vary in terms of materials, competences and meanings, and there is no 'one size fits all' solution that would work in all contexts [70]. Also, if tailoring involves interaction with intermediaries, such as energy advisers, it is more likely to build competences that can engender concrete changes in energy-using practices. The potential of intermediaries for building competences in low-carbon ways of living has been recognised in previous studies, e.g., Reference [71]. There is also some indication that targeting particular practices such as showering, (via separate smart meter displays next to the shower) [72] or heating (measuring gas consumption with a smart meter and providing tailored, userand building specific advice to lower room temperatures through an in-home display) [73], may be successful in decreasing the resource consumption in these practices. From a practice theories point of view, this creates a stronger link to certain practices than providing information on (inconspicuous) energy or water consumption in general, which results from various domestic practices that are not always easily separable from each other.

\subsubsection{Potentials Related to Materials and Infrastructures}

Smart meter feedback happens in a material context, which consists of the built infrastructure, resource flows and appliances of the household. Currently, these are often unsupportive of low-carbon ways of living. Thus, only few potentials related to the material context were identified in the literature (Table 6).

Combining smart meter feedback with microgeneration can be seen not only as creating new material elements to practices but also to the competences and meanings associated with domestic energy-using practices. Only four of the studies we analysed included households that were micro-producers of solar power. Microgeneration provides potentially an entry point to a radically different relationship to energy [46] (p. 90), as confirmed by two of the studies in our sample [52,62], in which some households with smart metering and photovoltaic panel installed adapted their domestic practices to match the solar peak periods. An analogy with farming was presented by a participant, referring to not wanting to waste the 'crops' one produces [62]. Meanings of self-sufficiency have in some trials also been found to be an important part of prosumerism [74]. It has been observed that becoming a prosumer requires certain competences that are evolving over 
time and requires integrating 'home grown' energy in everyday practices [70]. However, in two of the reviewed studies $[31,63]$, similar impacts were not observed.

Table 6. Potentials of smart meter feedback related to materials and infrastructures as identified in the literature and as interpreted through theories of social practice.

\begin{tabular}{cr}
\hline \multicolumn{2}{c}{ Potentials of Smart Meter Feedback Related to Materials and Infrastructures } \\
\hline \multicolumn{1}{c}{ Identified in the Literature } & Interpreted through Theories of Social Practice \\
$\begin{array}{c}\text { Linking engagement with smart meter } \\
\text { feedback to an existing activity such as } \\
\text { watching TV [65]. }\end{array}$ & $\begin{array}{r}\text { Practice theories may help to explain why in one study, } \\
\text { where smart meter feedback could be viewed on TV, } \\
\text { it became the most popular medium of engaging with it. } \\
\text { It was connected to an existing practice and its material } \\
\text { element (TV) and associated with commercial breaks. }\end{array}$ \\
$\begin{array}{c}\text { Smart meter feedback combined with } \\
\text { microgeneration of solar energy can engender } \\
\text { changes in the way energy is used [31,52,62]. }\end{array}$ & $\begin{array}{r}\text { Participating in the production of intermittent solar energy } \\
\text { can change the configuration and rhythm of certain } \\
\text { practices by reconfiguring the meaning of energy in } \\
\text { domestic practices as something that is temporally limited. }\end{array}$ \\
\hline
\end{tabular}

The above mentioned examples indicate that micro-generation, when used as a complementary source of energy and still having a constant and reliable access to centralised power grid, does not necessarily challenge existing practices and energy intensive ways of life, while the situation is completely different for practitioners 'off-the-grid', who have to organise their practices and daily rhythms based on the availability of energy [12] (pp. 135-154)). The different responses by households in the reviewed literature are of interest as all households in the studies we reviewed were connected to the centralised grid. The reasons for successes (or failures) are beyond our study but would be a topic to address in future research.

\subsubsection{Potentials Related to Socially Shared Meanings}

Socially and culturally shared meanings and conventions are deeply embedded in and shape the practices using energy and water. Potentials related to shared meanings that have been identified in our sample of reviewed studies are presented in Table 7.

Communities hold potential for shaping practices towards a more sustainable direction through experimentation and peer learning. The way knowledge is shared and becomes part of practices for example among frontrunner households that experiment with sustainable energy technologies, includes interaction with peers, home visits and conversations face to face or in online communities [9-11]. This is very different from most of the reviewed literature where individuals or families receive abstract consumption information that is not shared with others, or sharing of it is not meaningful as it is not linked to any other activities of the community (if there even is one). However, some of the analysed studies recognise the potential of supporting communities in feedback experiments [31,67]. It can also be argued that 'frontrunner' households experimenting with smart meter feedback and presenting the monitoring systems to their peers serve to promote a potentially emerging practice of energy monitoring [46].

Several of the reviewed studies argue that smart meter feedback should look beyond individuals and instead focus on and try to understand household dynamics and the community context in which feedback is received $[49,51,55,60,63-65,67]$. One of the studies [60] also suggest that providing smart meters to households as part of broader collective efforts and partnerships on energy conservation could make a difference regarding how actively residents engage in using them. In our survey, one of the key issues identified for the effectiveness of smart metering was linking smart metering to other energy or water saving actions such as energy coaching or awareness raising campaigns. 
Table 7. Potentials of smart meter feedback related to socially shared meanings as identified in the literature and as interpreted through theories of social practice.

\begin{tabular}{|c|c|}
\hline \multicolumn{2}{|c|}{ Potentials of Smart Meter Feedback Related to Socially Shared Meanings } \\
\hline Identified in the Literature & Interpreted through Theories of Practice \\
\hline $\begin{array}{l}\text { Combining smart meter feedback with community-level } \\
\text { action on energy or water conservation, such as } \\
\text { workshops and group discussions }[51,67] \text {. } \\
\text { Residents taking part in smart meter feedback trials } \\
\text { feeling proud of the system and presenting it to their } \\
\text { peers, which can have potential spillover effects outside } \\
\text { the household }[52,53,60,65] \text {. }\end{array}$ & $\begin{array}{l}\text { Social networks such as communities are } \\
\text { important for the diffusion of practices. Thus, } \\
\text { community-level activities together with smart } \\
\text { meter trials may help to create and support a } \\
\text { community of practice, in which social learning } \\
\text { takes place, ideas are shared, and utilising smart } \\
\text { meter feedback could take root as a practice. }\end{array}$ \\
\hline $\begin{array}{l}\text { Smart meter feedback playing other roles and attaining } \\
\text { other meanings than the management of energy or water } \\
\text { consumption: source of reassurance when being able to } \\
\text { predict the size of the next bill, a tool for controlling } \\
\text { family members, providing security and maintaining } \\
\text { sense of togetherness between family members who are } \\
\text { located separately or a tool for detecting failures, leaks, } \\
\text { incorrect billing or underperformance of } \\
\text { PV-panels }[52,59,60,63,64] \text {. }\end{array}$ & $\begin{array}{l}\text { Meanings attached to certain elements of } \\
\text { practices are always on the move and their } \\
\text { development is to some extent unpredictable. } \\
\text { Smart meters, when entering household } \\
\text { contexts, are likely to attain other meanings } \\
\text { than those originally intended. This may affect } \\
\text { consumption negatively or positively. For } \\
\text { example, using smart meter feedback to detect } \\
\text { system failures and thus improving the } \\
\text { performance of e.g., PV-panels decreases the } \\
\text { climate impacts of a household even if did not } \\
\text { affect the ways energy is actually consumed. }\end{array}$ \\
\hline
\end{tabular}

Social networks such as communities are important for the diffusion of practices, and it is also within these that practices can change [32]. Building trust and establishing a community partnership based on social, face-to-face interaction in the community e.g., in the form of home energy assessments have been recognised as key success factors in some community-based energy interventions [75,76]. Personal contacts with intermediaries have been linked to better effectiveness of feedback interventions [77]. In the light of practice theories, community-level activities could also be integrated into smart meter feedback initiatives, as they would help to create and support a community of practice in which social learning takes place, ideas are shared and utilising smart meter feedback could take hold as a practice, which would provide peer-support and help to build new competences. However, this does not happen automatically and belonging to a certain geographic community or neighbourhood is not necessarily enough for a community of practice to emerge [78].

Some of the reviewed studies $[55,57]$ call for policies and smart metering strategies that would challenge what is seen as 'normal' everyday consumption, by using existing policy techniques to support low-carbon social practices and even experimenting with radical policy measures such as personal carbon allowances [55]. It has been suggested that smart meter feedback could, instead of providing only consumption data, concentrate on the meanings and competences associated with certain practices and give advice on how they could be performed differently [57]. These suggestions resonate with practice theories, as they would radically shape the meanings and competences related to energy and water consuming practices. However, these suggestions should be further developed and empirically studied in order to find out their potential in a real-life setting.

\section{Discussion}

This paper is an attempt to look at smart meter feedback and the challenges and potentials associated with it from the point of view of practice theories. One guiding question in practice theories when looking at energy use is 'What is energy for?' [30]. As the behaviour change paradigm ' $\mathrm{ABC}$ ' and practice theories ask different questions, interpreting the challenges and potentials of smart metering from a point of view of practice theories is not a straightforward task. Based on our analysis it seems that it is especially fruitful to use practice theories to reframe challenges that are usually seen 
as individuals' lack of interest or knowledge or their love of comfort. When these are not framed as characteristics of the individuals but understood as being integral parts of normalised, socially shared practices that are shaped by the material arrangements of our everyday environments, new opportunities for intervention can emerge.

Attempts to affect the 'tip of the iceberg', the observable behaviour of individuals (see Section 1) without recognising the material features, competences and shared understandings that underpin visible behaviour, miss an opportunity to shape the elements of which practices are made and thus affect their sustainability in the long term. Smart meter feedback attempts to improve the efficiency of the 'performance' of various practices and in this it has sometimes succeeded. Some residents do reduce 'excess' consumption of energy and water at least in the initial phase of smart metering trials. Residents taking part in smart meter feedback trials typically describe undertaking various 'curtailment' behaviours such as turning off lights or appliances that are not in use (e.g., [52,53,57]). However, it seems that this does not contribute to the sustainability of energy and water consuming practices as a whole, the practices as entities. On the contrary, several developments within homes are pointing towards more energy-intensive ways of life [12,39], and various smart technologies may even reinforce this trend $[79,80]$.

Smart metering and other smart home appliances are often marketed to consumers as a way of managing resource use without compromising certain lifestyle or level of comfort [12] (p. 26). Smart meter feedback and its sustainability should be viewed and evaluated as part of a wider development where ICT has an increasing role in various domestic practices [81]. Homes are becoming equipped with smart appliances and home-automation. Smart meter feedback systems are also becoming more developed and complex, integrating many kinds of data, e.g., Reference [82]. Attention has been paid to the possible drawbacks of smart home technologies, as they could create new energy-demanding practices, and new expectations of normality related to comfort, convenience, entertainment, security and health may rise as a result of increasing smart features in homes $[80,83,84]$. The escalating character of such expectations is also of concern [39]. Many smart meter feedback devices are marketed and used together with other smart home features which have several functions, energy management being only one of them, and not necessarily the most important one for residents or marketers of these systems [79].

As argued earlier in this paper, the assumption of residents being rational individuals that actively make decisions based on smart meter feedback is strongly built in smart meter feedback initiatives. The examples described in the reviewed literature can be interpreted in a way that the idealised energy consumer is to some extent present in the smart meter trials, appealing to few, perhaps technologically enthusiastic members of a household. The 'Resource Man' is very similar to the description of an active energy citizen, whose emergence seems to be a precondition but not a guarantee for the effectiveness of smart meter feedback and for participating in smart grids. This is very far from the everyday reality of how energy and water consumption is an unconscious and embedded part of our everyday living.

If the unit of change is social practice rather than individual choice as theories of social practice suggest, interventions based on the emergence of active energy citizens or 'Resource Men' cannot achieve a true transition. However, it has been recognised that community energy schemes involving microgeneration may be able to change the residents' relationship to energy by making it more salient. Thus, for residents who produce energy through microgeneration and consume it, energy can become an active component in their practices, instead of something that is taken for granted. It has been argued that microgeneration or community energy schemes should be an essential part of introducing smart meters and that without them rollouts of smart meters are 'likely to be a missed opportunity' [8]. On the other hand, engagement does not happen automatically, as observed in Section 4.2.2, and conventional smart meter feedback may not even serve the needs of prosumers [85]. Members of energy cooperatives have been reported to quickly lose interest in engaging with the feedback and finding it difficult to shift activities to the solar peak periods of the day [31]. This brings us back to the importance of looking at practices rather than individuals. If the interlinked and 
sequenced practices where energy and water are used are not temporally flexible enough and if their competences do not relate to the conservation of energy and water, simply introducing consumption feedback is not enough.

An analysis of the ongoing implementation of the UK smart meter roll-out programme has identified barriers related to technology, vulnerability and resistance and given policy recommendations to overcome these barriers. The recommendations include, among others, early engagement with residents, recognising lack of trust and concerns over security and privacy, assessing how smart meters connect with prosumption, assessing how smart metering affects vulnerable groups and conducting lifecycle analysis on smart meters [61].

The policy recommendations [61] are likely to improve the technical reliability, transparency and acceptability of the smart meter roll-out as a project, as well as its environmental sustainability. However, they do not question the effectiveness of smart meter feedback as such. The third recommendation (assessing how smart meters connect with prosumption) may be crucial for the future effectiveness of smart metering, as microgeneration has potential for making energy a more important element in the practices where it is used.

A shift towards low-carbon ways of living does not necessarily require feedback but more fundamental changes in the socio-technical system of energy provision and consumption. This transition is not only a technical matter but is likely to deeply affect our society and culture [86]. Examples in the literature we have analysed belong almost solely to the category of early first order innovations [46] (see Section 2), while second and third order innovations are almost totally missing, with the exception of some examples where the timing of domestic practices had been adapted as a result of microgeneration of solar energy [52,62]. It could be argued that in order for smart meter feedback to be effective, it should be implemented only in a context where second and third order innovations are supported, advancing a wider transition towards low-carbon energy systems. There is not one straightforward and easy way to make practice-based policy. Rather, policy based on an understanding of practice as a unit of change instead of an individual, can take many forms and utilise many currently existing policy instruments. However, the fundamental difference is that practice-based policymaking is not targeted at persuading individuals to change their behaviour as a result of incentives or information but rather creating conditions for more sustainable practices to take hold and recruit practitioners from less sustainable ones [32]. An important first step is to build an understanding of practices as a unit of societal change.

\section{Conclusions}

Smart metering technologies are politically popular and there is confidence in their role in reducing consumption. However, there is also a growing body of literature challenging the assumption that making energy or water consumption data visible or accessible will make residents use energy and water differently.

Challenges of smart meter feedback are to a great extent related to the resource-intensity of current domestic practices, including all their elements: infrastructures and appliances, competences and skills as well as shared meanings. Practices do change, but they cannot be changed simply by providing consumption feedback to residents. Energy and water are generally not featuring as elements in domestic practices but operating in the background and taken for granted in current provision systems. This is why residents are generally not interested in monitoring their consumption and why feedback often seems abstract and irrelevant to them and makes them defensive. To change this will require a transition where saving energy starts to matter, e.g. through increasing competences related to microgeneration and energy communities. At the same time, expectations of normality when it comes to standards of living, comfort and cleanliness, should change towards directions that are less energy intensive. This requires policies that address practices rather than individuals.

Smart meter feedback has managed to successfully engage some residents who are experimenting with energy or water management. They can be seen as pioneers of an emerging 'home energy 
management (HEM) practice'. Whether this practice will successfully recruit more practitioners and eventually have an effect on energy consumption will depend on several developments within energy provision and the role of energy and water in domestic practices. By itself, monitoring is not enough if it does not lead to any or more than minor decreases in consumption.

Monitoring and data collection are increasingly becoming an element of various practices as a result of digitalisation and development of monitoring technologies. For example, monitoring body functions and physical performance has become more popular as part of exercise routines and fostering well-being. It could be argued that as monitoring gains ground in different spheres, it can also become part of domestic energy and water using practices. However, there is a risk that efficiency gains from home energy management will not keep up with the increasing levels of consumption due to rising standards and expectations that come along with the increasing smartness of home environments.

Researchers have an important role to play in contributing to the discussion around smart metering and how it is framed. Is it a project to activate individuals to make informed choices when using energy and water? Or could it be a project to transform the meanings related to energy and water consuming practices, together with an ongoing, (though still in its initial phase) transition towards a de-centralised renewable energy supply system?

We argue that in order to increase the impact of smart meter feedback, it should be developed as an embedded part of the practice arrangements, not as a stand-alone technological solution to measure resource consumption in households. Its relevance for energy and water using practices could be improved by combining it with microgeneration, thus creating an opportunity for energy-monitoring practices to emerge and become more established. This would require simultaneously supporting a wider energy transition towards a low-carbon society, involving second and third order innovations that would create a link between current domestic practices and currently non-existent HEM-practices. Participatory, household or community-level approaches with active involvement of intermediaries can also support the building of new competences and meanings related to the use of smart meter feedback in performing domestic practices. At the same time, material trends in home environments and domestic practices that have implications on what is regarded as normal standard of living should be carefully monitored and their links to policy identified.

Author Contributions: Conceptualisation, M.H.; H.M.; K.M.; J.P.; M.S. methodology, M.H.; H.M.; J.P.; M.S. formal analysis, H.M.; writing—original draft preparation, H.M.; writing-review and editing, M.H.; H.M.; K.M.; J.P.; M.S. supervision, M.H. funding acquisition, M.H.; J.P.

Funding: This research was funded by the Academy of Finland Strategic Research Council, project Dwellers in Agile Cities (DAC), grant number 303481. The contribution of M.S. was supported by Kone Foundation.

Conflicts of Interest: The authors declare no conflict of interest.

\section{Appendix A}

List of reviewed studies. Full references to the studies are available in References. When describing type of feedback we use terminology that has been used in the articles themselves, e.g., energy monitor or in-home display. 
Table A1. List of reviewed core literature.

\begin{tabular}{|c|c|c|c|c|}
\hline $\begin{array}{l}\text { Quantitative Changes in } \\
\text { Consumption (if any) }\end{array}$ & Qualitative Study Setting & Duration of Experiment (if applicable) & Type of Feedback & Authors \\
\hline Not measured. & 19 households interviewed & 9 months & \multirow{2}{*}{$\begin{array}{l}\text { In-home display for electricity consumption. } \\
\text { In-home display for electricity, water and } \\
\text { gas consumption. }\end{array}$} & Barnicoat \& Danson 2015 \\
\hline Not measured & 25 households interviewed & Between 1 and 4 years & & Berry et al., 2017 \\
\hline Not measured. & 5 households interviewed & 5 months & $\begin{array}{l}\text { Home energy monitor, solar panels and other } \\
\text { energy efficiency devices. }\end{array}$ & Bickerstaff et al., 2016 \\
\hline Not measured. & $\begin{array}{l}125 \text { user reviews of in-home } \\
\text { displays }\end{array}$ & Not applicable & In-home display for electricity consumption. & Buchanan et al., 2014 \\
\hline Not measured. & 30 households interviewed & 2 years & $\begin{array}{l}\text { In-home display for electricity. Weekly e-mails and } \\
\text { community activities. }\end{array}$ & Burchell et al., 2016 \\
\hline $\begin{array}{l}6.8 \% \text { decrease after one year, } 6.4 \% \\
\text { after } 5 \text { years }\end{array}$ & $\begin{array}{l}82 \text { households included in the } \\
\text { study, does not specify how many } \\
\text { were interviewed. }\end{array}$ & 1 year + a longitudinal study of 5 years & In-home display for water consumption & Davies et al. 2014 \\
\hline $8.1 \%$ decrease & 20 households interviewed & 5 months & In-home display for electricity consumption & Grønhøj \& Thøgersen 2011 \\
\hline Not measured & 112 blogposts on smart meters & Over one year & $\begin{array}{l}\text { Smart electricity meter with real-time } \\
\text { consumption data }\end{array}$ & Guerreiro et al., 2015 \\
\hline Not measured & 15 households interviewed & $1-12$ months, in average 5.8 months. & $\begin{array}{l}\text { In-home display for electricity consumption, some } \\
\text { models also for heating and hot water. }\end{array}$ & Hargreaves et al., 2010 \\
\hline Not measured & 11 households interviewed & Over one year & $\begin{array}{l}\text { In-home display for electricity, some models also } \\
\text { for heating and hot water. }\end{array}$ & Hargreaves et al., 2013 \\
\hline Not measured & 21 households interviewed & Over 6 months & In-home display for electricity consumption & Murtagh et al., 2014 \\
\hline No changes in consumption & 9 households interviewed & Approximately 4 months & In-home display for electricity consumption & Nilsson et al., 2014 \\
\hline Not measured & 17 individuals interviewed & 3 weeks & In-home display for electricity consumption & Oltra et al., 2013 \\
\hline Not measured & 7 households interviewed & 18 months & $\begin{array}{l}\text { Smart electricity meter with monitoring sottware. } \\
\text { Consumption data could be accessed via TV, } \\
\text { computer, tablet or mobile phone. }\end{array}$ & Schwartz et al., 2014 \\
\hline Not measured & $\begin{array}{l}9 \text { self-authored videos and } 3 \\
\text { interviews with households }\end{array}$ & $4-6$ months & $\begin{array}{l}\text { In-home display for electricity, gas and } \\
\text { water consumption }\end{array}$ & Snow et al., 2015 \\
\hline Not measured & 28 households interviewed & From 2 months to 2 years & $\begin{array}{l}\text { In-home display for electricity. One model also } \\
\text { measuring water and gas consumption, room } \\
\text { temperature and solar power production. }\end{array}$ & Strengers 2011 \\
\hline Not measured & 7 individuals interviewed & 6 months & $\begin{array}{l}\text { Smart meter data (electricity and gas) on a website } \\
\text { and a smart phone app }\end{array}$ & Verkade \& Höffken 2017 \\
\hline Not measured & 21 households interviewed & 3-6 weeks & In-home display for electricity consumption & Wallenborn et al., 2011 \\
\hline $\begin{array}{l}12.3 \% \text { reduction in one pilot study, } \\
\text { not measured in another pilot. }\end{array}$ & 33 households interviewed & From 1 month to 1.5 years & In-home display for electricity consumption & Westskog et al. 2015 \\
\hline Not measured & $\begin{array}{l}24 \text { individuals interviewed, } \\
5 \text { focus group discussions with } \\
21 \text { participants }\end{array}$ & Approximately 3 months & In-home display for electricity consumption. & Winther \& Bell 2018 \\
\hline
\end{tabular}




\section{References}

1. Girod, B.; van Vuuren, D.P.; Hertwich, E.G. Climate policy through changing consumption choices: Options and obstacles for reducing greenhouse gas emissions. Glob. Environ. Chang. 2014, 25, 5-15. [CrossRef]

2. Mekonnen, M.M.; Hoekstra, A.Y. Four billion people facing severe water scarcity. Sci. Adv. 2016, 2, 1-6. [CrossRef] [PubMed]

3. Torriti, J.; Hassan, M.; Leach, M. Demand response experiences in Europe: Policies, programmes and implementation. Energy 2010, 35, 1575-1583. [CrossRef]

4. Siano, P. Demand response and smart grids-A survey. Renew. Sustain. Energy Rev. 2014, 30, 461-478. [CrossRef]

5. Araújo, K. The Emerging Field of Energy Transitions: Progress, Challenges, and Opportunities. Energy Res. Soc. Sci. 2014, 1, 112-121. [CrossRef]

6. Sovacool, B. How long will it take? Conceptualizing the temporal dynamics of energy transitions. Energy Res. Soc. Sci. 2016, 13, 202-215. [CrossRef]

7. van Vliet, B.J.M. Sustainable innovation in network-bound systems: Implications for the consumption of water, waste water and electricity services. J. Environ. Policy Plan. 2012, 14, 263-278. [CrossRef]

8. Goulden, M.; Bedwell, B.; Rennick-Egglestone, S.; Rodden, T.; Spence, A. Smart grids, smart users? The role of the user in demand side management. Energy Res. Soc. Sci. 2014, 2, 21-29. [CrossRef]

9. Hyysalo, S.; Juntunen, J.; Freeman, S. User innovation in sustainable home energy technologies. Energy Policy 2013, 55, 490-500. [CrossRef]

10. Hyysalo, S.; Juntunen, J.; Freeman, S. Internet forums and the rise of the inventive energy user. Sci. Technol. Stud. 2013, 26, 25-51.

11. Jalas, M.; Hyysalo, S.; Heiskanen, E.; Lovio, R.; Nissinen, A.; Mattinen, M.; Rinkinen, J.; Juntunen, J.K.; Tainio, P.; Nissilä, H. Everyday experimentation in energy transition: A practice theoretical view. J. Clean. Prod. 2017, 169, 77-84. [CrossRef]

12. Strengers, Y. Smart Energy Technologies in Everyday Life: Smart Utopia? Palgrave Macmillan: Hampshire, UK, 2013; ISBN 978-1-349-44325-3.

13. Darby, S. Smart metering: What potential for householder engagement? Build. Res. Inf. 2010, 38, $442-457$. [CrossRef]

14. Sonderlund, A.L.; Smith, J.R.; Hutton, C.; Kapelan, Z.; Savic, D. Effectiveness of smart-meter based consumption feedback in curbing household water use: Knowns and unknowns. J. Water Resour. Plan. Manag. 2016, 142. [CrossRef]

15. Darby, S. Literature Review for the Energy Demand Research Project; Environmental Change Institute: Oxford, UK, 2010; pp. 17-24.

16. USmartConsumer 2016. European Smart Metering Landscape Report "Utilities and Consumers". USmartConsumer Project. Available online: http://www.escansa.es/usmartconsumer/documentos / USmartConsumer_European_Landscape_Report_2016_web.pdf (accessed on 7 February 2017).

17. European Commission. Energy Efficiency Directive 2012/27/EU. Available online: https: / / eur-lex.europa. eu/legal-content/EN/TXT/?uri=celex:32012L0027 (accessed on 21 August 2018).

18. European Commission. Towards an Integrated Strategic Energy Technology (SET) Plan: Accelerating the European Energy System Transformation. Available online: https:/ /ec.europa.eu/energy/sites/ener/files/ documents/1_EN_ACT_part1_v8_0.pdf (accessed on 21 August 2018).

19. Darby, S. The Effectiveness of Feedback on Energy Consumption. A Review for Defra of the Literature on Metering, Billing and Direct Displays; Environmental Change Institute: Oxford, UK, 2003; p. 3.

20. Fischer, C. Feedback on household electricity consumption: A tool for saving energy? Energy Effic. 2008, 1, 79-104. [CrossRef]

21. Faruqui, A.; Sergici, S.; Sharif, A. The impact of information feedback on energy consumption-A survey of the experimental evidence. Energy 2009, 35, 1598-1608. [CrossRef]

22. Delmas, M.A.; Fischlein, M.; Asensio, O.I. Information strategies and energy conservation behavior: A meta-analysis of experimental studies from 1975 to 2012. Energy Policy 2013, 61, 729-739. [CrossRef]

23. Klopfert, F.; Wallenborn, G. Empowering Consumers through Smart Metering, a Report for the BEUC; Bureau Europeen des Unions des Consommateurs (BEUC): Brussels, Belgium, 2011; p. 2. 
24. Allen, D.; Janda, K. The Effects of Household Characteristics and Energy Use Consciousness on the Effectiveness of Real-Time Energy Use Feedback: A Pilot Study. In Proceedings of the ACEEE 2006 Summer Study on Energy Efficiency in Buildings; American Council for an Energy-Efficient Economy: Washington, DC, USA, 2006; pp. 1-12.

25. Alahmad, M.A.; Wheeler, P.G.; Schwer, A.; Eiden, J.; Brumbaugh, A. A Comparative Study of Three Feedback Devices for Residential Real-Time Energy Monitoring. IEEE Trans. Ind. Electron. 2012, 59, 2002-2013. [CrossRef]

26. Abrahamse, W.; Steg, L.; Vlek, C.; Rothengatter, T. A Review of Intervention Studies Aimed at Household Energy Conservation. J. Environ. Psychol. 2005, 25, 273-291. [CrossRef]

27. Wallenborn, G.; Orsini, M.; Vanhaverbeke, J. Household appropriation of electricity monitors. Int. J. Consum. Stud. 2011, 35, 146-152. [CrossRef]

28. Buchanan, K.; Russo, R.; Anderson, B. The question of energy reduction: The problem(s) with feedback. Energy Policy 2015, 77, 89-96. [CrossRef]

29. Hargreaves, T. Beyond energy feedback. Build. Res. Inf. 2018, 46, 332-342. [CrossRef]

30. Shove, E.; Walker, G. What Is Energy For? Social Practice and Energy Demand. Theory Cult. Soc. 2014, 31, 41-58. [CrossRef]

31. Verkade, N.; Höffken, J. Is the Resource Man coming home? Engaging with an energy monitoring platform to foster flexible energy consumption in the Netherlands. Energy Res. Soc. Sci. 2017, 27, 36-44. [CrossRef]

32. Shove, E.; Pantzar, M.; Watson, M. The Dynamics of Social Practice: Everyday Life and How It Changes; Sage: London, UK, 2012; ISBN 978-0-85702-043-7.

33. Spaargaren, G. Theories of practices: Agency, technology, and culture: Exploring the relevance of practice theories for the governance of sustainable consumption practices in the new world-order. Glob. Environ. Chang. 2011, 21, 813-822. [CrossRef]

34. Giddens, A. The Constitution of Society; Polity Press: Cambridge, UK, 1984; ISBN 0745600069.

35. Schatzki, T. The Site of the Social: A Philosophical Account of the Constitution of Social Life and Change; Penn State Press: University Park, PA, USA, 2002; ISBN 978-0-271-02292-5.

36. Reckwitz, A. Toward a theory of social practices: A development in culturalist theorizing. Eur. J. Soc. Theory 2002, 5, 243-263. [CrossRef]

37. Shove, E.; Watson, M.; Hand, M.; Ingram, J. The Design of Everyday Life; Berg: Oxford, UK, 2007; ISBN 1845206835.

38. Spurling, N.; McMeekin, A.; Shove, E.; Southerton, D.; Welch, D. Interventions in Practice: Re-Framing Policy Approaches to Consumer Behavior. Available online: http:/ /www.sprg.ac.uk/uploads/sprg-reportsept-2013.pdf (accessed on 21 September 2018).

39. Shove, E. Comfort, Cleanliness and Convenience: The Social Organization of Normality; Berg: Oxford, UK, 2003; ISBN 9781859736302.

40. Hand, M.; Shove, E.; Southerton, D. Explaining Showering: A Discussion of the Material, Conventional, and Temporal Dimensions of Practice. Sociol. Res. Online 2005. [CrossRef]

41. Yates, L.; Evans, D. Dirtying Linen: Re-evaluating the sustainability of domestic laundry. Environ. Pol. Gov. 2016, 26, 101-115. [CrossRef]

42. Warde, A. Consumption and Theories of Practice. J. Consum. Cult. 2005, 5, 131-153. [CrossRef]

43. Heiskanen, E.; Johnson, M.; Robinson, S.; Vadovics, E.; Saastamoinen, M. Low-carbon communities as a context for individual behavioural change. Energy Policy 2010, 38, 7586-7595. [CrossRef]

44. Shove, E. Beyond the ABC: Climate Change Policy and Theories of Social Change. Environ. Plan. A Econ. Space 2010, 42, 1273-1285. [CrossRef]

45. Ajzen, I. The theory of planned behaviour. Organ. Behav. Hum. Decis. Process. 1991, 50, 179-211. [CrossRef]

46. Naus, J. The Social Dynamics of Smart Grids: On Households, Information Flows \& Sustainable Energy Transitions. Ph.D. Thesis, Wageningen University, Wageningen, The Netherlands, 2017. [CrossRef]

47. Torraco, R.J. Writing Integrative Literature Reviews: Guidelines and examples. Hum. Resour. Dev. Rev. 2005, 4, 356-367. [CrossRef]

48. Barnicoat, G.; Danson, M. The Ageing Population and Smart Metering: A Field Study of Householders' Attitudes and Behaviours towards Energy Use in Scotland. Energy Res. Soc. Sci. 2015, 9, 107-115. [CrossRef]

49. Guerreiro, S.; Batel, S.; Lima, M.L.; Moreira, S. Making energy visible: Sociopsychological aspects associated with the use of smart meters. Energy Effic. 2015, 8, 1149-1167. [CrossRef] 
50. Nilsson, A.; Jakobsson Bergstad, C.; Thuvander, L.; Andersson, D.; Andersson, K.; Meiling, P. Effects of continuous feedback on households' electricity consumption: Potentials and barriers. Appl. Energy 2014, 122, 17-23. [CrossRef]

51. Oltra, C.; Boso, A.; Espluga, J.; Prades, A. A qualitative study of users' engagement with real-time feedback from in-house energy consumption displays. Energy Policy 2013, 61, 788-792. [CrossRef]

52. Berry, S.; Whaley, D.; Saman, W.; Davidson, K. Finding faults and influencing consumption: The role of in-home energy feedback displays in managing high-tech homes. Energy Effic. 2017, 10, 787-807. [CrossRef]

53. Winther, T.; Bell, S. Domesticating in home displays in selected British and Norwegian households. Sci. Technol. Stud. 2018, 31, 19-38. [CrossRef]

54. Davies, K.; Doolan, C.; van den Honert, R.; Shi, R. Water-saving impacts of Smart Meter technology: An empirical 5 year, whole-of-community study in Sydney, Australia. Water Resour. Res. 2014, 50, 7348-7358. [CrossRef]

55. Hargreaves, T.; Nye, M.; Burgess, J. Keeping energy visible? Exploring how householders interact with feedback from smart energy monitors in the longer term. Energy Policy 2013, 52, 126-134. [CrossRef]

56. Buchanan, K.; Russo, R.; Anderson, B. Feeding back about eco-feedback: How do consumers use and respond to energy monitors? Energy Policy 2014, 73, 138-146. [CrossRef]

57. Strengers, Y. Negotiating everyday life: The role of energy and water consumption feedback. J. Consum. Cult. 2011, 11, 319-338. [CrossRef]

58. Murtagh, N.; Gatersleben, B.; Uzzell, D. 20:60:20—Differences in Energy Behaviour and Conservation between and within Households with Electricity Monitors. PLoS ONE 2014, 9, 1-12. [CrossRef] [PubMed]

59. Westskog, H.; Winther, T.; Sæle, H. The Effects of In-Home Displays-Revisiting the Context. Sustainability 2015, 7, 5431-5451. [CrossRef]

60. Hargreaves, T.; Nye, M.; Burgess, J. Making energy visible: A qualitative field study of how householders interact with feedback from smart energy monitors. Energy Policy 2010, 38, 6111-6119. [CrossRef]

61. Sovacool, B.; Kivimaa, P.; Hielscher, S.; Jenkins, K. Vulnerability and resistance in the United Kingdom's smart meter transition. Energy Policy 2017, 109, 767-781. [CrossRef]

62. Bickerstaff, K.; Hinton, E.; Bulkeley, H. Decarbonisation at home: The contingent politics of experimental domestic energy technologies. Environ. Plan. A 2016, 48, 2006-2025. [CrossRef]

63. Snow, S.; Vyas, D.; Brereton, M. When an eco-feedback system joins the family. Pers. Ubiquit. Comput. 2015, 19, 929-940. [CrossRef]

64. Grønhøj, A.; Thøgersen, J. Feedback on household electricity consumption: Learning and social influence processes. Int. J. Consum. Stud. 2011, 35, 138-145. [CrossRef]

65. Schwartz, T.; Stevens, G.; Jakobi, T.; Denef, S.; Ramirez, L.; Wulf, V.; Randall, D. What People Do with Consumption Feedback: A Long-Term Living Lab Study of a Home Energy Management System. Interact. Comput. 2015, 27, 551-576. [CrossRef]

66. Powells, G.; Bulkeley, H.; Bell, S.; Judson, E. Peak electricity demand and the flexibility of everyday life. Geoforum 2014, 55, 43-52. [CrossRef]

67. Burchell, K.; Rettie, R.; Roberts, T.C. Householder engagement with energy consumption feedback: The role of community action and communications. Energy Policy 2016, 88, 178-186. [CrossRef]

68. Peacock, A.D.; Chaney, J.; Goldbach, K.; Walker, G.; Tuohy, P.; Santonja, S.; Todoli, D.; Owens, E.H. Co-designing the next generation of home energy management systems with lead-users. Appl. Ergon. 2017, 60, 194-206. [CrossRef] [PubMed]

69. Novak, J.; Melenhorst, M.; Micheel, I.; Pasini, C.; Fraternali, P.; Rizzoli, A.E. Integrating behavioural change and gamified incentive modelling for stimulating water saving. Environ. Model. Softw. 2018, 102, 120-137. [CrossRef]

70. Hansen, M.; Hauge, B. Prosumers and smart grid technologies in Denmark: Developing user competences in smart grid households. Energy Effic. 2017, 10, 1215-1234. [CrossRef]

71. Salo, M.; Nissinen, A.; Lilja, R.; Olkanen, E.; O’Neill, M.; Uotinen, M. Tailored advice and services to enhance sustainable household consumption in Finland. J. Clean. Prod. 2016, 121, 200-207. [CrossRef]

72. Tiefenbeck, V.; Goette, L.; Degen, K.; Tasic, V.; Fleisch, V.; Lalive, R.; Staake, T. Overcoming Salience Bias: How Real-Time Feedback Fosters Resource Conservation. Manag. Sci. 2018, 64, 1458-1476. [CrossRef] 
73. Mogles, N.; Walker, I.; Ramallo-Gonzáles, A.P.; Lee, J.; Natarajan, S.; Padget, J.; Gabe-Thomas, E.; Lovett, T.; Ren, G.; Hyniewska, S.; et al. How smart do smart meters need to be? Build. Environ. 2017, 125, 439-450. [CrossRef]

74. Wittenberg, I.; Matthies, E. How do PV households use their PV system and how is this related to their energy use? Renew. Energy 2018, 122, 291-300. [CrossRef]

75. Morris, P.; Vine, D.; Buys, L. Critical success factors for peak electricity demand reduction: Insights from a successful intervention in a small island community. J. Consum. Policy 2018, 41, 33-54. [CrossRef]

76. Heiskanen, E.; Johnson, M.; Vadovics, E. Learning about and involving users in energy saving on the local level. J. Clean. Prod. 2013, 48, 241-249. [CrossRef]

77. Gupta, R.; Barnfield, L.; Gregg, M. Exploring innovative community and household energy feedback approaches. Build. Res. Inf. 2018, 46, 284-299. [CrossRef]

78. Hitchings, R. Sharing conventions. Communities of practice and thermal comfort. In Sustainable Practices. Social Theory and Climate Change; Shove, E., Spurling, N., Eds.; Routledge Advances in Sociology: London, UK, 2013; pp. 103-115, ISBN 978-0-415-54065-0.

79. Strengers, Y.; Nicholls, L. Convenience and energy consumption in the smart home of the future: Industry visions from Australia and beyond. Energy Res. Soc. Sci. 2017, 32, 86-93. [CrossRef]

80. Tirado Herrero, S.; Nicholls, L.; Strengers, Y. Smart home technologies in everyday life: Do they address key energy challenges in households? Curr. Opin. Environ. Sustain. 2018, 31, 65-70. [CrossRef]

81. Røpke, I.; Christensen, T.H.; Jensen, J.O. Information and communication technologies-A new round of household electrification. Energy Policy 2010, 38, 1764-1773. [CrossRef]

82. Francisco, A.; Truong, H.; Khosrowpour, A.; Taylor, J.E.; Mohammadi, N. Occupant perceptions of building information model-based energy visualizations in eco-feedback systems. Appl. Energy 2018, 221, 220-228. [CrossRef]

83. Nyborg, S.; Røpke, I. Energy impacts of the smart home-Conflicting visions. Energy Efficiency First: The Foundation of a Low-Carbon Society. In Proceedings of the ECEEE 2011 Summer Study, Belambra Presquile de Giens, France, 6-11 June 2011; European Council for an Energy Efficient Economy: Stockholm, Sweden, 2011; pp. 1849-1860.

84. Darby, S. Smart technology in the home: Time for more clarity. Build. Res. Inf. 2018, 46, 140-147. [CrossRef]

85. Miller, W.; Senadeera, M. Social transition from energy consumers to prosumers: Rethinking the purpose and functionality of eco-feedback technologies. Sustain. Cities Soc. 2017, 35, 615-625. [CrossRef]

86. Järvensivu, P. A post-fossil fuel transition experiment: Exploring cultural dimensions from a practice-theoretical perspective. J. Clean. Prod. 2017, 169, 143-151. [CrossRef] 